\title{
SUPPLEMENTARY ACCOUNT OF THE BIRDS OF THE VIRGIN ISLANDS, INCLUDING CULEBRA AND ADJACENT ISLETS PERTAINING TO PUERTO RICO, WITH NOTES ON THEIR FOOD HABITS
}

\author{
By Stuart T. DANForth
}

Professor of Zoölogy and Entomology, College of Agriculture and Mechanics Arts.

\section{INTRODUCTION}

This paper is intended as a supplement to my "Bird Records from the Virgin Islands", published in the Journal of the Department of Agriculture of Porto Rico, Vol. XIV, no. 3 (July, 1930). Since that paper was published it has been my privilege to continue ornithological observations in some of the islands previously visited, and to extend my investigations to a number of additional islands, some of which had not previously been visited by an ornithologist. Reports on three small but important collections of birds from St. Croix generously presented by Mr. Harry A. Beatty of that island are also included in this paper.

\section{ITINERARIES}

In 1931 a short visit was made to St. Thomas and St. Croix en route to other islands on June 16, and on the return trip the period from August 12 to 15 was spent on St. Thomas. During this short stay paroquets were obtained.

In 1933 and 1934, with Mr. Angel Biaggi as assistant, a short collecting trip was made to St. Thomas and some of the British Virgin Islands. We arrived in St. Thomas very early in the morning of December 23, and worked there until the afternoon of December 27, when we went by motor launch to Tortola, where we stayed for a week, except for a half day visit which we made on December 28 to Beef Island, and the day of January 1, which we spent on Jost van Dyke. On this trip we also passed close enough to Great Thatch Island to make some bird observations. Neither Beef Island nor Jost van Dyke had previously received a visit from an ornithologist. Early in the morning of January 4 we left by sloop for Puerto Rico, stopping for a short stay in St. Thomas that afternoon, and arriving in Puerto Rico the next day.

In 1934 and 1935, accompanied by Mr. Robustino Biaggi as assistant, some collecting was done in Culebra and adjacent islets. 
We arrived at Culebra on the night of December 25, and stayed there until the morning of January 4. During this time we made one-day trips by sloop on December 28 to Louis Peña, on December 30 to Cayo Norte, and on January 1 to Culebrita. No ornithologist had previously visited Cayo Norte.

In the summer of 1935, with Mr. Virgilio Biaggi, Jr., as assistant, the period from June 14 to 19 was spent in St. Thomas while waiting for a boat to other islands. During this time we did some collecting on St. Thomas, and on June 18 made a visit to the nearby islet of Little Saba where there is an enormous nesting colony of Zenaida Doves, and several species of terns also apparently nest. Upon our return from the southern islands we made another very brief visit to St. Croix and St. Thomas on August 14.

\section{PlaN OF WORK}

In the annotated list of the birds records of all species which were not previously recorded by the writer from the island in question are given. Additional records of birds seen or captured which were listed in the previous paper from islands visited before that paper was written are given from those islands only in the case of rare species, or when additional information of importance concerning that species in the island previously visited has been secured. All species seen or collected on islands not previously visited by the writer are recorded in this paper, and mention of all the specimens from St. Croix received from Mr. Beatty. Notes have been included whenever possible on the results of analyses of stomach contents of the birds collected. Brief descriptions of islands not previously visited are given, and at the end will be found an appendix giving a complete list of all the birds known to occur in the Virgin Islands, including Vieques, Culebra and other smaller islands to the east of Puerto Rico, with a statement as to which island each bird is known to inhabit or visit.

In this connection it might be in order to mention the small collection of birds in the St. Thomas High School, which it was my privilege to inspect in June, 1935. This collection, which is aged and musty and of unknown origin, evidently consists in the main of specimens from St. Thomas, but none of the specimens are accompanied by data, and a few are evidently from St. Croix or even from places outside the Virgin Islands; so these specimens cannot be considered as constituting valid records for St. Thomas. This is regrettable, as there are in the collection a number of specimens 
which would be valuable as records or for purposes of comparison if it could be proved that they had come from St. Thomas. Among these I might make mention of specimens of Fulica caribaea, Rallus longirostris subsp., Haematopus palliatus, Erismatura jamaicensis jamaicensis, Dendrocygna arborea, Saurothera vieilloti, Colinus vir. ginianus, and two specimens of Spatula clypeata.

\section{Brief Descriptions of Islands not Previously Visited}

Culebra is an irregularly shaped island twenty miles east of Puerto Rico. It is about six miles long, and three miles wide at the widest point. Its surface is mostly hilly, with the highest peak rising to 650 feet. On the south coast there is a deep indentation known as Bahia Honda, the shores of which have in most places a narrow fringe of mangroves. Some of the hills are covered with a xerophytic type of forest. There are no permanent streams on the island. In the northwest part of the island there is a large brackish water lagoon known as Flamenco Lagoon. At times waterbirds are said to abound there, but very few were present at the time of our visit. The town is situated at the base of the peninsula which forms the southern shore of Bahia Honda. The island possesses 847 inhabitants.

Louis Peña, sometimes known as Southwest Cay, is situated about a mile south of Culebra. It is slightly over a mile in length, and has a wooded hill 476 feet in height. The island is mostly grown to brush, but in a few places on the hills there are some high woods of a xerophytic type. There is a slight bit of level land and a tiny brackish lagoon in the neck of land connecting the southern knob with the main part of the island. The coasts are for the most part very rocky. Two families inhabit the island to care for a few cattle which are raised there.

Culebrita, about a mile in length, is situated less than a mile from the eastern and of Culebra. It has a trihedral shape, with three prongs extending into the ocean. At the center is a hill 305 feet in height capped by a lighthouse. Near the tip of the southwest prong is an extensive brackish lagoon where some ducks occur, and there is another very small lagoon nearer the center of the island. The island is almost completely covered with dense brush of a spiny nature, with very few paths, so we negotiated the three prongs with great difficulty. On the southern prong there are some abrupt rocky cliffs, the vicinity of which is frequented by Oystereatchers. 
Cayo Norte (also known as Northeast Cay) is about a mile off the north coast of Culebra, and a little over a mile northwest of Culebrita. It is slightly over a mile in length, and is mostly covered with dry scrub, which becomes high xerophytic woodland on the highland, which attains an elevation of 338 feet. There is a small brackish lagoon much grown with mangroves near the south coast. The northeast part of the island is rocky headland. The island is the property of Don Eduardo Padró and his brothers and sister. $\mathrm{He}$ and one of his brothers, and a family of negro squatters live on the island. He gave us a very hearty welcome to the island and assisted us greatly during the day we were there, which he was able to do particularly well due to his intimate knowledge of the birds of his island.

Jost van Dyke is a hilly island about four miles in length and one and a quarter miles in width situated about three miles northwest of Tortola. There are three bays on the south coast, these, in order from west to east, being White Bay, Great Harbour (where the "town" of perhaps a dozen houses is situated), and Plain Bay. We went to Jost van Dyke by motor launch from Tortola, and went ashore at each of the three bays, working the country in all directions from each landing place. Near White Bay there is a brackish lagoon several acres in extent, and near Plain Bay there are two much smaller ones. Near Great Harbour there is a dense mangrove swamp. The island is so hilly that there is practically no level land on it. The highest peak attains an elevation of 1,070 feet above sea level. There are about two hundred inhabitants (all black) on the island. They have made numerous clearings and small plantations, but the larger part of the island is covered with brush.

Great Thatch Island is a long, narrow, brush-covered island lying directly west of Tortola. It is about two miles long, with a precipitous shoreline; its highest point is 613 feet above sea level. It is uninhabited at present, although a few people have lived there at various times in the past. We had no opportunity to go ashore on it, but on several occasions passed so close to its shores in small boats that it was possible to make observations even of small land birds.

Beef Island is an island slightly over two and a half miles in length situated directly east of Tortola and separated from it by a narrow strait. The western part of the island is rather low, partially cultivated, and has three lagoons which contain slightly 
brackish water. The two largest are sufficiently fresh to permit of the growth of Naias and other fresh-water pondweeds, though brackish enough to have a few mangroves growing along their banks. Ducks, coots, and grebes occurred in one. The third is more brackish, and has a denser growth of mangroves. The eastern part of the island is more rugged, and boasts of a hill 660 feet in height. The island has two inhabitants.

\section{Remaris on the Avifauna}

The birds of the Virgin Islands, despite their great similarity to those of Puerto Rico in many respects, also show striking affinities to those of the Lesser Antilles, despite the fact that they are removed from the Lesser Antilles by the broad Anegada Channel eighty miles or more in width, whereas the nearer of this group of islands are very close to and plainly visible from Puerto Rico. Most of the Puerto Rican birds which reach the Virgin Islands are those in which either the identical or a closely related form extends into the Lesser Antilles, whereas such typically Lesser Antillean forms as Orthorhynchos exilis exilis, Sericotes holosericeus holosericeus and Elaenia martinica riisii abound in the Virgin Islands, and either do not reach Puerto Rico at all, or are very scarce and found only in extreme eastern Puerto Rico. Therefore the avifauna of the Virgin Islands may be regarded as intermediate between Lesser Antillean and Greater Antillean, but approaching more closely to the former. Only four forms of birds are peculiar to the Virgin Islands, namely Amazona vittata gracilipes of Culebra (now extinct); Gymnasio nudipes newtoni of St. Thomas, St. Jan, St. Croix and possibly Vieques (likewise now extinct); Coereba portoricensis sanctithomae of practically all the Virgin Islands except St. Croix; and Coereba newtoni of St. Croix.

The total list of birds, including migrants and accidental visitors, definitely recorded from the Virgin Islands adds up to 133 forms. This is a rather meagre avifauna, but it is to be expected, due to the small size of the islands, and their remoteness from continental land masses. The absence of certain genera which occur commonly in both the Greater and Lesser Antilles from these islands (except in some cases Vieques, which due to its close proximity to Puerto Rico boasts of more of the characteristic birds of Puerto Rico than any other of the islands under discussion) is noteworthy. Among such 
genera might be mentioned Myiarchus, Blacicus, Holoquiscalus, Tanagra and Loxigilla.

\section{ANNOTATED LIST \\ Podilymbus podiceps antillarum Bangs Antillean Grebe}

On December 28, 1933 an adult was observed by its nest on the slightly brackish lagoon at Beef Island. The nest was a floating affair made of fresh green pondweeds. Mr. H. C. Beatty has sent me an adult female in breeding plumage with black throat and band on bill which he obtained at South Gate Pond, St. Croix, on December 31, 1933. It exhibits the following measurements: Culmen from base 26.8 ; exposed culmen 21.5 ; wing 122.4 ; tarsus 36.9 millimeters. The measurements are similar to those of North American birds, but the colors can be matched closely by breeding birds from Puerto Rico and Antigua in my collection.

\section{Pelecanus occidentalis occidentalis Linnaeus Brown Pelican}

A few observed on Culebra December 27, 1934, to January 3, 1935; on Louis Peña December 28, 1934; Culebrita January 1, 1935; Cayo Norte December 30, 1934, and Beef Island December 28, 1933. Common at Great Thatch Island January 1, 1934, and on Jost van Dyke the same day Pelicans were remarkably abundant, perhaps 300 being noted, mostly adult birds with white heads and chestnut red necks.

\section{Sula leucogaster leucogaster (Boddaert) \\ Brown Booby}

Seen at Culebra January 5, 1934, and December 27, 1934, to January 1, 1935; at Louis Peña December 28, 1934; Great Thatch Island January 1, 1934; Jost van Dyke January 1, 1934, and Little Saba June 18, 1935.

\section{Fragata magnificens rothschildi Mathews Man-o-war Bird}

One seen at Culebra January 6, 1934, and another December 27, 1934; one at Culebrita January 1, 1935; three at Jost van Dyke January 1, 1934, and one at Beef Island December 28, 1933. 


\section{Ardea herodias herodias Linnaeus Great Blue Heron}

Individuals were noted at Culebra on December 27 and 28, 1934, and on Culebrita January 1, 1935. There is some uncertainty as to whether birds occurring in this region are migrants from North America or a resident West Indian form. Although I have no specimens from North America at hand for comparison, it might not be amiss in this connection to present the measurements of specimens from the West Indies in my collection:

\begin{tabular}{|c|c|c|c|c|}
\hline & Wing & Tail & $\begin{array}{l}\text { Exposed } \\
\text { Culmen }\end{array}$ & Tarsus \\
\hline No. 551, female, Great Bay, St. Martin, Dec. $24,1927 \ldots \ldots$ & 425.6 & 165.7 & 125.3 & 150.5 \\
\hline No. 660 , male, Añasco, Puerto Rico................... & 471.5 & 183.3 & 143.0 & 180.1 \\
\hline No. 1507, Cabo Rojo, Puerto Rico, female...... & 433.7 & & 123.1 & 154.2 \\
\hline
\end{tabular}

The above measurements are expressed in millimeters.

\section{Florida caerulea caerulescens (Latham)}

Southern Little Blue Heron

Common on Culebra December 26, 1934, to January 3, 1935. A bird in white plumage was collected on December 26. Its stomach contained 9 fiddler crabs (Uca pugnax rapax). One in adult blue plumage was collected at a tiny lagoon on Louis Peña December 28,1934 , and its stomach was found to contain a crab of the same species. Two were observed on Cayo Norte December 28, 1934, and nineteen on Jost van Dyke January 1, 1934.

\section{Butorides virescens maculatus (Boddaert) West Indian Green Heron}

Rather scarce on Culebra, two being seen on December 29, 1934, and three on January 3, 1935 . One was noted on Culebrita January 1, 1935, and two on Cayo Norte December 30, 1934. Six were seen on Jost van Dyke January 1, 1934.

\section{Casmerodius albus egretta (Gmelin) American Egret}

One was shot at Mosquito Bay, St. Thomas, on June 17, 1935, but it was impossible to recover the bird. 


\section{Nyctanassa violacea violacea (Linnaeus) Yellow-crowned Night Heron}

A few immature birds were observed in mangrove swamps on Culebra December 31, 1934, and January 3, 1935.

\section{Dafila bahamensis bahamensis (Linnaeus) Bahama Duck}

A flock of twelve was seen at the lagoon on Culebrita January 1, 1935. On January 1, 1934 twenty-five were noted at three small brackish ponds on Jost van Dyke, and a male was collected. Its stomach contained Persicaria seeds and a little sand. On December 28,1933 a flock of twenty was observed at the lagoon on Beef Island. One was seen at a lagoon on the south coast of St. Thomas on June 17, 1935, and another the next day on Little Saba island.

\section{Nyroca affinis (Eyton) \\ Lesser Scaup Duck}

A male and two females were noted on Flamenco Lagoon, Culebra, on December 27, 1934. Mr. Beatty sent me a female obtained on South Gate Pond, St. Croix, March 26, 1933.

\section{Erismatura jamaicensis jamaicensis (Gmelin) \\ West Indian Ruddy Duck}

Mr. Beatty forwarded a male in breeding plumage (now No. 1157 in my collection) which he obtained on South Gate Pond, St. Croix on August 28, 1933. It shows the following measurements: Culmen 40.5 ; breadth of bill at widest part 23.6; wing (arc) 133.4; wing (flat) 138.7; tarsus 28.4 millimeters.

\section{Buteo jamaicensis jamaicensis (Gmelin) \\ West Indian Red-tailed Hawk}

One was observed at the east and of Culebra December 30, 1934, and one on Cayo Norte the same day. On Jost van Dyke the species was not actually seen, but was accurately described to me by residents.

\section{Falco columbarius columbarius Linnaeus Pigeon Hawk}

One was shot but not recovered in the eastern part of St. Thomas on December 24, 1933. 


\section{Falco sparverius loquaculus (Riley)}

Puerto Rican Sparrow Hawk

Abundant on Culebra and Louis Peña; very scarce on Cayo Norte and Culebrita. On Cayo Norte, where one was seen on December 30, 1934, Don Eduardo Padró assured me that only one pair existed. One was seen on Culebrita on January 1, 1935. A female was collected on Culebra on December 26, 1934, and another female or. Louis Peña on December 28, 1934. The latter had eaten 2 Sphaerodactylus lizards and a Schistocerca grasshopper. One was collected on Jost van Dyke January 1, 1934. Its stomach contained 2 mole crickets (Scapteriscus vicinus), and 2 rather large spiders. The stomach from Culebra contained 5 field crickets (Gryllus assimilis), 82 per cent; 6 caterpillars ( 3 of them Pyralidae), 10 per cent; fragments of fur and skin of a mouse, 8 per cent. A Sparrow Hawk was noted on St. Thomas on June 16, 1933.

\section{Rallus longirostris subsp. Clapper Rail}

Many were heard in the mangroves on Culebra on December 26 and 29, 1934, and on the former date a female was collected. Mr. Beatty has sent me a male which he collected at Krause Lagoon, St. Croix, on April 13, 1935.

\section{Porzana carolina (Linnaeus) Sora Rail}

A male was collected on Tortola, in the mangroves in a lagoon at Brandywine Bay on December 31, 1933. Its stomach contained comminuted Hemiptera (apparently Zaitha anura), 65 per cent; and seeds of Persicaria, 35 per cent.

\section{Gallinula chloropus portoricensis Danforth Antillean Gallinule}

Two were noted in a small mangrove swamp on Cayo Norte December 30, 1934. On St. Thomas eight were observed at some mangrove bordered lagoons near the east end of the island on December 24, 1934, and a female (No. 1042) was collected. Its stomach contained the leaves of pondweed and sand. Eighteen were noted on Jost van Dyke January 1, 1934; and fifteen at Brandywine Bay, Tortola December 31, 1933, and a few at the lagoon on Beef Island December 28, 1933. Mr. Beatty has forwarded three specimens from St. Croix, a female (No. 1153) taken at William Pond November 12, 1933; another (No. 1154) from South Gate Pond 
December 31, 1933, and a half-grown young one (No. 1155) from William Pond April 6, 1934. The measurements of the three adult specimens follow, expressed in millimeters :

\begin{tabular}{|c|c|c|c|c|c|c|c|}
\hline & $\begin{array}{l}\text { Wing } \\
\text { (arc) }\end{array}$ & $\begin{array}{c}\text { Wing } \\
\text { (flat) }\end{array}$ & $\begin{array}{c}\text { Culmen } \\
\text { with } \\
\text { frontal } \\
\text { shield }\end{array}$ & Tarsus & $\begin{array}{l}\text { Bill } \\
\text { from } \\
\text { gape }\end{array}$ & $\begin{array}{l}\text { Width } \\
\text { of } \\
\text { frontal } \\
\text { shield }\end{array}$ & Tail \\
\hline Female, No. $1042 \ldots \ldots \ldots \ldots$ & 158.8 & 163.5 & 45.3 & 46.4 & 28.8 & 14.6 & \\
\hline Female, No. $1153 \ldots \ldots \ldots \ldots$ & 150.0 & 152.3 & 46.1 & 51.7 & 28.0 & 15.5 & 69.1 \\
\hline Female, No. $1154 .$. & 173.3 & 177.8 & 44.0 & 52.6 & 28.7 & 13.7 & 72.3 \\
\hline
\end{tabular}

\section{Fulica americana americana Gmelin American Coot}

The coots of St. Croix are somewhat confusing. Mr. Beatty has sent me eight specimens from there. Of these one is definitely $F$. americana. The rest have been identified as $F$. caribaea, but two of them appear to be intermediate between the two species, having a small amount of red at the top of the frontal shield, which, however, dries wrinkled, whereas the skin on the frontal shields of $F$. americana dries smooth. The specimen which is unquestionably $F$. americana (No. 1152) is a male secured on South Gate Pond April 21, 1934, and showis the following measurements: Wing (arc) 195.6; wing (flat) 202.0 ; tail 54.3; culmen with frontal shield 49.8 ; depth of bill at base 17.2; width of frontal plate 9.2 ; length of frontal plate 15.6; tarsus 59.6 millimeters. The frontal shield is less swollen than in specimens of $F$. a. grenadensis from Jamaica in my collection, and the measurements in general are greater, so I am listing the bird, at least provisionally, as $F$. a. americana.

\section{Fulica caribaea Ridgway \\ Caribbean Coot}

Mention has been made under the preceding species of the confusion existing regarding the coots of St. Croix. Measurements are herewith appended of the seven specimens listed as $F$. caribaea forwarded by Mr. Beatty. The two specimens which exhibit some characteristics of $F$. americana are numbers 1068 and 1069; these were submitted to Dr. Alexander Wetmore for examination, and pronounced by him to be $F$. caribaea. The other five specimens are thoroughly typical specimens of $F$. caribaea. The measurements are expressed in milimeters : 


\begin{tabular}{|c|c|c|c|c|c|c|c|c|}
\hline Specimen & $\begin{array}{l}\text { Wing } \\
\text { (arc) }\end{array}$ & $\begin{array}{l}\text { Wing } \\
\text { (flat) }\end{array}$ & Tail & $\begin{array}{l}\text { Culmen } \\
\text { with } \\
\text { frontal } \\
\text { shield }\end{array}$ & $\begin{array}{l}\text { Depth } \\
\text { of bill } \\
\text { at } \\
\text { base }\end{array}$ & $\begin{array}{l}\text { Length } \\
\text { of } \\
\text { frontal } \\
\text { plate }\end{array}$ & $\begin{array}{l}\text { Width } \\
\text { of } \\
\text { frontal } \\
\text { plate }\end{array}$ & Tarsus \\
\hline $\begin{array}{l}\text { No. 1147, male, } \\
\text { South Gate Pond, } \\
\text { February } 3,1934\end{array}$ & $\ldots \quad 183.5$ & 193.5 & 49.6 & 54.9 & 18.0 & 19.4 & 10.8 & 59.5 \\
\hline $\begin{array}{l}\text { No. 1149, maje, } \\
\text { South Gate Pond, } \\
\text { February } 3,1934\end{array}$ & 186.7 & 191.0 & 54.1 & 53.0 & 17.0 & 20.4 & 11.5 & 57.5 \\
\hline $\begin{array}{l}\text { No. 1151, female, } \\
\text { South Gate Pond, } \\
\text { April 21, } 1934\end{array}$ & 171.0 & 180.5 & 47.2 & 45.8 & 15.1 & 13.7 & 9.4 & 55.7 \\
\hline $\begin{array}{l}\text { No. 1150, female } \\
\text { South Gate Pond, } \\
\text { March 23, } 1934\end{array}$ & 164.0 & 171.5 & 50.6 & 50.0 & 15.2 & 18.5 & 9.7 & 51.6 \\
\hline $\begin{array}{l}\text { No. 1148, female, } \\
\text { Rust-up-twist Pond, } \\
\text { December } 31,1933\end{array}$ & 168.0 & 178.0 & 51.8 & 51.5 & 14.8 & 22.0 & 11.0 & 56.5 \\
\hline $\begin{array}{l}\text { No. 1068, Sex? } \\
\text { South Gate Pond, } \\
\text { March } 26,1933\end{array}$ & 172.6 & 181.0 & 48.0 & 47.4 & 16.3 & 17.8 & 9.9 & 51.9 \\
\hline $\begin{array}{l}\text { No. } 1069 \text {, Sex? } \\
\text { South Gate Pond, } \\
\text { March 26, } 1933\end{array}$ & 184.8 & 191.0 & 52.0 & 46.8 & 16.5 & 16.3 & 8.8 & 52.4 \\
\hline
\end{tabular}

A coot apparently of this species was noted at White Bay on Jost van Dyke January 1, 1934, and ten on the brackish lagoon on Beef Island December 28, 1933. One of the latter was shot, but it proved impossible to recover the specimen.

\section{Haematopus palliatus prattii Maynard Bahaman Oyster-catcher}

Two were seen along the rocky shore of Louis Peña on December 28 , 1934, and three on the rocky eastern point of Culebrita on January 1, 1935. All were too wary to permit of getting within shooting range of them. Don Eduardo Padró reports that they occur regularly in winter on Cayo Norte. One was seen at Coffy Point, Tortola, on December 31, 1933. There is a specimen, presumably from St. Thomas, in the collection of the St. Thomas High School.

\section{Charadrius vociferus vociferus Linnaeus}

\section{Killdeer}

A winter visitor, locally common in the Virgin Islands. On Culebra many were seen from December 26 to 30, 1934, at mudholes by small streams, in swampy fields, and also at Flamenco Lagoon 
and in mangrove swamps. The stomachs of two birds collected contained exclusively insects, of which Coleoptera, mainly Bembidion and Staphylinidae, formed 60 per cent, and Stratiomyid larvae 40 per cent.

One was noted on the shore at Cayo Norte on December 30, 1934. Mr. Beatty has presented me with a female taken in a plowed field on the Bethlehem Estate, St. Croix, on January 5, 1935 . Records from other islands are included in my previous paper.

All Killdeers in my collection from islands east of Puerto Rico, and from continental North America, are darker and average larger than specimens from the Dominican Republic and Puerto Rico, and are evidently migrants from North America, as they are very rarely seen in these islands in the summer. They may all be considered as Charadrius $v$. vociferus. Although it would seem that this form must oceur in Puerto Rico, at least during migrations, I have seen no specimens from there, all those in my collection being typical C. $v$. ternominatus (distinctly lighter in color, and averaging smaller in size.) An example seen, but not collected, at Mosquito Bay, St. Thomas on June 17, 1935, constitutes my only summer Killdeer record for these islands. It may have belonged to the latter race. The measurements of the Killdeers in my collection (expressed in millimeters) are herewith presented.

CHARADRIUS VOCIFERUS VOCIFERUS

\begin{tabular}{|c|c|c|c|c|}
\hline Specimen & Wing & $\begin{array}{c}\text { Culmen } \\
\text { from } \\
\text { base }\end{array}$ & Tail & Tarsus \\
\hline No. 1232 , male, Culebra, Dec. $26,1934 \ldots \ldots \ldots \ldots \ldots \ldots$ & 153.6 & 24.3 & 93.6 & 36.4 \\
\hline No. 1255 , male, Culebra, Dec. $29,1934 \ldots \ldots \ldots \ldots \ldots \ldots \ldots$ & 157.7 & 26.0 & 89.6 & 35.2 \\
\hline No. 707 , male, St. Thomas, Jan. $4,1929 \ldots \ldots \ldots \ldots \ldots \ldots$ & 159.5 & 25.1 & 92.0 & 34.0 \\
\hline No. 693 , male, Salt Island, Dec. $29,1928 \ldots \ldots \ldots \ldots \ldots \ldots$ & 157.1 & 24.8 & 96.9 & 33.5 \\
\hline No. 557 , male, St. Martin, Dec. $24,1927 \ldots \ldots \ldots \ldots \ldots \ldots$ & 162.8 & 24.5 & 91.8 & 33.9 \\
\hline No. 1505 , female, St. Croix, Jan. $5,1935 \ldots \ldots \ldots \ldots \ldots \ldots$ & 162.7 & 28.0 & 96.0 & 35.0 \\
\hline No. 1307 , male, Yakima, Washington, Oct. $19,1933 \ldots \ldots \ldots$ & 167.3 & 25.9 & 99.5 & 35.4 \\
\hline No. 1308 , female, Yakima, Washington, Oct, $19.1933 \ldots \ldots$ & 156.9 & 26.0 & 94.8 & 35.5 \\
\hline No. 20, female, Havre de Grace, Md., Apr. 16, $1926 \ldots \ldots$. & 162.5 & 25.7 & 97.6 & 34.8 \\
\hline
\end{tabular}


CHARADRIUS VOCIFERUS TERNOMINATUS

\begin{tabular}{|c|c|c|c|c|}
\hline Specimen & Wing & $\begin{array}{l}\text { Culmen } \\
\text { from } \\
\text { base }\end{array}$ & Tail & Tarsus \\
\hline No. 410 , male, Haina, R. D., June $16,1927 \ldots \ldots \ldots \ldots \ldots$ & 147.8 & 25.0 & 85.1 & 35.0 \\
\hline No. 22 , male, Arecibo, P. R., Oct. $14,1926 \ldots \ldots \ldots \ldots \ldots$ & 145.5 & 25.8 & 90.0 & 36.1 \\
\hline No. 21 , male, Laguna Cartagena, P. R., Sept. $23,1924 \ldots$. & 139.6 & 23.4 & 93.0 & 33.8 \\
\hline No. 885 , male, Laguna de Guánica, P. R., Apr. 29, 1933.... & 143.2 & 25.0 & 84.7 & 35.2 \\
\hline No. 1173, male, Laguna de Guánica, P. R., Oct. $6,1934 \ldots . .$. & 145.4 & 25.8 & 92.1 & 36.0 \\
\hline No. 1066, female, Laguna de Gúanica, P. R., Jan. 12, $1934 \ldots$. & 154.1 & 26.2 & 92.7 & 35.8 \\
\hline
\end{tabular}

Charadrius hiaticula semipalmatus Bonaparte Semipalmated Plover

A male collected on the seacoast at Enfield Green. St. Croix, on November 1, 1933, was received from Mr. Beatty.

\section{Pagolla wilsonia rufinucha (Ridgway) Rufous-naped Plover}

The male of a pair seen on a small sandy beach at Little Saba on June 18, 1935, was collected. Its stomach eontained two small seeds and an earwig.

\section{Tringa flavipes (Gmelin) \\ Lesser Yellowlegs} 1933.

One was noted at Brandywine Creek, Tortola, on December 31,

$$
\begin{gathered}
\text { Tringa melanoleuca (Gmelin) } \\
\text { Greater Yellowlegs }
\end{gathered}
$$

Two were seen at a lagoon on Beef Island December 28, 1933.

\section{Actitis macularia (Linnaeus) \\ Spotted Sandpiper}

Fairly common on Culebra from December 26, 1934, to January 3, 1935. On the latter date a male was collected. Its stomach contained fragments of a small crab. Two were observed at the tiny lagoon on Louis Peña on December 28, 1934, and two on Jost van Dyke on January 1, 1934. The stomach of a male collected 
at Brandywine Creek, Tortola, on December 31, 1933, contained a small crab, Hippa sp.

\section{Catoptrophorus semipalmatus inornatus (Brewster) Western Willet}

A female collected by Mr. Beatty at Hammer Pond, St. Croix, on October 24, 1933, constitutes the first record for the West Indies. It is now No. 1161 in my collection. It shows the following measurements: Wing 213.0 ; culmen from base 70.5 ; tarsus 64.8 ; tail 85.0 millimeters.

\section{Aremaria interpres morinella (Linnaeus) Ruddy Turnstone}

Fifteen were observed at Flamenco Lagoon; Culebra, on December 27, 1934. Mr. Beatty sent a male obtained on the seacoast at Enfield Green, St. Croix, on November 1, 1933.

\section{Limnodromus griseus griseus (Gmelin) Dowitcher}

Two specimens in winter plumage from St. Croix, sex unknown, were received from Mr. Beatty. One was obtained at the Salt Pond on November 26, 1933, and one at Krausse Lagoon on April 1, 1934.

\section{Capella delicata (Ord) \\ Wilson's Snipe}

Two were seen near Roadtown, Tortola, on December 29, 1933. A male collected at William Pond, St. Croix, on November 5, 1933, was received from Mr. Beatty.

\section{Crocethia alba (Pallas) Sanderling:}

A male obtained on Krausse Lagoon, St. Croix, January 1, 1934, was received from Mr. Beatty.

Ereunetes pusillus (Linnaeus)

Semipalmated Sandpiper

Mr. Beatty sent a female collected on the seacoast at Enfield Green, St. Croix, on November 1, 1933. 


\section{Ereunetes mauri Cabanis \\ Western Sandpiper}

A female of a pair seen was collected at the slightly brackish lagoon at Beef Island on December 28, 1933. Its stomach contained nothing but sand. This constitutes the first record for the Virgin Islands.

\section{Erolia melanotos (Vieillot) \\ Pectoral Sandpiper}

A male collected at Camp Watch Ho Pond, St. Croix, on October 29, 1933, was received from Mr. Beatty.

\section{Micropalama himantopus (Bonaparte) \\ Stilt Sandpiper}

Mr. Beatty sent a female collected at the Salt Pond, St. Croix, on January 1, 1934, constituting the second record for the Virgin Islands.

\section{Himantopus himantopus mexicamus (P. L. S. Müller) \\ Black-necked-Stilt}

Four were seen at a salt lagoon on the south coast of St. Thomas on Auguist 14, 1931, and two at the small lagoon on Little Saba June 18, 1935.

\section{Larus atricilla Linnaeus \\ Laughing Gull}

Many were observed at St. Thomas in June and August, 1931, July, 1933, and June, 1935, when a male was collected; also at Frederiksted, St. Croix, August 12, 1931, and July 23, 1933. At Little Saba on June 18, 1935, the species was abundant, but apparently not nesting.

\section{Sterna dougallii dougallï Montagu Roseate Tern}

Six were observed in the harbor at St. Thomas on June 15, 1935, and many along the south coast on June 18. On the latter date about fifty were resting on the rocks at Little Saba, but gave no indications of nesting at the time.

\section{Sterna albifrons antillarum (Lesson) Least Tern}

Two were observed along the south coast of St. Thomas on June 17, 1935. 


\section{Sterna anaethetus melanoptera Swainson Bridled Tern}

Several were seen near the south coast of St. Thomas on June 18, 1935. The same day many were observed apparently nesting or preparing to nest on Little Saba and Flat Key, although no eggs or young were found. A male was collected on Little Saba. Its stomach contained fragments of a small crab.

\section{Sterna fuscata fuscata Linnaeus Sooty Tern}

One was seen a half mile off the south coast of St. Thomas on July 23, 1933, and many nearer the coast on June 18, 1935. On the latter date the species was found to be abundant and apparently nesting on Little Saba, although no nests were found. A male, with empty stomach, was collected.

\section{Thalasseus maximus maximus (Boddaert) Royal Tern}

Five were observed at Jost van Dyke on January 1, 1934.

\section{Anoüs stolidus stolidus (Linnaeus) \\ Noddy Tern}

One was noted half a mile off the south coast of St. Thomas on July 23, 1933, and many at and close to the coast on June 18, 1935. The same day the species was abundant around the rocky cliffs on Little Saba, and apparently nesting, although it was impossible to reach any of the nests. The stomach of a male collected there contained fragments of Crustaceans.

\section{Columba leucocephala Linnaeus \\ White-crowned Pigeon}

One was seen in the mangroves on Culebra on January 3, 1935.

\section{Columba squamosa Bonnaterre Scaled Pigeon}

One was observed on Culebra January 3, 1935; ten in the denser woods on Louis Peña on December 28, 1934, and six on a wooded hilltop on Cayo Norte on December 30, 1934. 


\section{Zenaida aurita zenaida (Bonaparte) Zenaida Dove}

On January 3, 1935, twenty were noted in the fringe of mangroves along the south shore of Bahía Honda in Culebra. One was seen on Culebrita on January 1, 1935.

On St. Thomas three were seen on August 14, 1933, and three more on July 23, 1933 . From June 15 to 18, 1935, they were seen commonly, and a male was collected on Signal Hill June 15. Its stomach contained a few partly digested seeds and some sand. On June 18 a visit was made to the enormous breeding colony on Little Saba. That entire islet serves as a breeding place for thousands of these doves, their nests being found everywhere from the shore to the highest peak, both on the ground and in the few available trees and bushes. The great majority of the nests were perforce upon the ground. These consisted merely of a few grasses laid upon the ground, and were placed in tunnel-like excavations under the matted grass which covered by far the greater part of the island. Incubating birds were flushed from these every few steps as one walked over the island. The nests in trees were the crude platforms of sticks typical of this family. On the date of our visit eggs in all stages from freshly laid to those on the point of hatching were found, and many young. Some of the latter were nearly full fledged. Four sets of eggs were collected and two fledglings were preserved as alcoholics. The measurements of the eggs are as follows: One set of 2 slightly incubated eggs measured $28.8 \times 21.8$ and $30.1 \times 22.6$ millimeters; a second set of 2 slightly incubated eggs measured $28.2 \times 20.8$ and $27.8 \times 21.6$ millimeters; a set of 2 very heavily incubated eggs measured $29.5 \times 22.8$ and $26.4 \times 21.8$ millimeters; and a single fresh egg measured $26.8 \times 20.9$ millimeters. The average measurements of the 7 eggs were $28.23 \times 21.76$ millimeters.

Hundreds of Zenaida Doves were observed flying across between their breeding colony on Little Saba and their feeding grounds on St. Thomas. In passing by Flat Key it was noted that these doves were apparently nesting there also. Little Saba is a bird reservation; nevertheless depredations are made upon the doves from time to time by residents of St. Thomas who desire a meal of juicy squabs.

Columbigallina passerina portoricensis (Lowe) Puerto Rican Ground Dove

Common on Culebra, where two were collected on December 29, 1934, and one on January 3, 1935. Abundant on Cayo Norte De- 
cember 30, 1934, when two males were collected; their stomachs contained a multitude of small triangular light brown seeds, and a few sunflowerlike seeds. Curiously enough, no Ground Doves were noted on Louis Peña or Culebrita. A male was collected on St. Thomas December 25, 1933. On June 15, 1935, a nest and eggs were collected on Signal Hill, St. Thomas. The nest was the usual very fragile platform of sticks, and was placed ten feet from the ground in an acacia tree. One of the two heavily incubated white eggs was accidentally broken in removing the nest; the other measured $21.9 \times 16.2$ millimeters. Half a dozen were seen on Little Saba on June 18, 1935.

One was collected at Brandywine Creek, Tortola, on December 31. 1933 ; its erop was jammed with an enormous number of small leguminous seeds. This species was common on Jost van Dyke January 1, 1934. The crop of a female collected there was filled with small seeds, mainly of grasses. Ground Doves were abundant on Beef Island December 28, 1933, where a female was collected. Its crop was full of seeds, including those of sticktights and grasses, and some large, flat leguminous seeds.

\section{Eupsittula pertinax pertinax (Linnaeus) Curaçao Paroquet}

After many vain attempts to secure paroquets on St. Thomas, my efforts were finally crowned with success on August 14, 1933, when a pair was collected while feeding on the fruits of a guenep tree in the southeastern part of the island. They were very tame while feeding, and after one bird of the pair was collected, the other came to investigate, and was also secured. A few other paroquets were heard in the same general vicinity at the time, but they are said to have become very scarce since the hurricane of 1928 . The measurements of the birds collected are: Male, No. 863, length (fresh) 283 ; extent 432 ; wing 134.9 ; culmen from base 25.4 ; tarsus 14.8; tail 116.1 millimeters. Female, No. 864, length (fresh) 263 ; extent 437 ; wing 138.8 ; culmen from base 25.2 ; tarsus 14.0 ; tail 117.0 millimeters.

\section{Coccyzus minor teres Peters Mangrove Cuckoo}

A female was collected in xerophytic scrub on Cayo Norte, where the species was reported to be searce, on December 30, 1934. Its stomach contents consisted entirely of Orthoptera and their eggs, 
including two large walking sticks (35 per cent); 1 grasshopper, Schistocerca colombina (20 per cent); 2 katydids, Microcentrum sp. (35 per cent); and 30 katydid eggs (10 per cent). One was observed at Signal Hill, St. Thomas, on June 15, 1935, and one in the western end of the island two days later. Two were noted at White Bay, Jost van Dyke, on January 1, 1934.

\section{Crotophaga ani Linnaeus Ani}

Abundant on Culebra December 26, 1934, to January 3, 1935. The stomach of a male collected December 26 contained a weevil (Diaprepes abbreviatus). Three large flocks were noted on Louis Peña December 28, 1933. The stomach of a female collected there contained 3 mole crickets, Scapteriscus vicinus, 90 per cent; and 2 small drupes, 10 per cent. Three flocks were seen on Culebrita January 1, 1935, and two flocks on Cayo Norte, December 30. 1934. On Jost van Dyke thirty Anis were seen on January 1, 1934, and one flock was noted on Beef Island December 28, 1933.

\section{Nephoecetes niger niger (Gmelin) Antillean Black Swift}

One was noted flying around in company with about twenty Martins at Frederiksted, St. Croix, on July 23, 1933, constituting the first record of the species for the Virgin Islands.

\section{Orthorhynchus exilis exilis (Gmelin) Gilt-crested Hummingbird}

On Culebra single birds were noted on December 27, 1934, and January 3, 1935. One was shot on Culebrita January 1, 1935. On Cayo Norte twenty were seen and three collected on December 30, 1934. The abundance of these hummers there was notable in comparison with their searcity on other nearby islands. Six were seen and a male collected on Jost van Dyke January 1, 1934.

\section{Sericotes holosericeus holosericeus (Linnaeus) Blue-breasted Hummingbird}

One was seen December 26, 1934, and five January 3, 1935, on Culebra. On the latter date two females were collected. Their stomachs contained fragments of small insects and spiders. On Culebrita fifteen were seen and two collected on January 1, 1935, 
the stomachs containing comminuted small insects. Ten were noted on Cayo Norte December 30, 1934, and a female was collected. Three were seen and two collected on Little Saba June 18, 1935. One was recorded on Beef Island December 28, 1933.

\section{Anthracothorax aurulentus (Audebert and Vieillot) Puerto Rican Mango}

This hummingbird, which is rather scarce in the Virgin Islands, was recorded only on Culebrita, where a male was collected on January 1, 1935.

\section{Megaceryle alcyon alcyon (Linnaeus)}

\section{Belted Kingfisher}

A regular migrant to the Virgin Islands. Seen regularly from December 26, 1934, to January 3, 1935 on Culebra, and on the latter date a female was collected. One was seen on Louis Peña December 28, 1934; two on Culebrita January 1, 1934; one on Cayo Norte December 30, 1934, and two on Jost van Dyke January 1, 1934.

\section{Tyrannus dominicensis dominicensis Gmelin Gray Kingbird}

Common in most of the Virgin Islands. The stomach of a male collected on Culebra December 27, 1934, contained a Tarantula Hawk (Pepsis rubra), 85 per cent; and two small drupes, 15 per cent. On Culebra this species occurred commonly on the north side of the island, and was searce near the town. Two were noted on Louis Peña December 28, 1934. None were observed on Culebrita, but they were common on Cayo Norte December 30, 1934, where a female was collected. It had eaten 80 per cent of animal matter (1 Histerid beetle, Omalodes klugii; 1 Cerambycid beetle, Elaphidion cinereum, 1 damselfly, and some other insects), and 20 per cent of vegetable matter ( 1 drupe). Kingbirds were common on Jost van Dyke January 1, 1934, and on Beef Island December 28, 1933, where a male was collected. Its stomach contained exclusively insects, mainly Hymenoptera. The species was recorded at Great Thatch Island January 4, 1934.

\section{Elaenia martinica riisii Sclater \\ Riise's Elaenia}

Common in most of the Virgin Islands. On Culebra it was fairly common from December 26, 1934, to January 3, 1935, and a male 
was collected on December 27 and a pair on January 3. These three stomachs contained 96.3 per cent of vegetable matter (drupes), and 3.7 per cent of animal matter (fleabeetles, Phyllotreta guatemalensis). On Louis Peña one was noted on December 28, 1934, and twelve on Culebrita January 1, 1935, where a male was collected. Its stomach contained two small lepidopterous larvae. On Cayo Norte it was remarkably abundant, its abundance being in fact one of the most striking features of the avifauna. It was known there by the name of "Jüi"'. Three males were collected there on December 30, 1934. Their stomachs contained small drupes and berries exclusively. The stomach of a female collected on St. Thomas December 25, 1933, was empty. Those of two collected there in June, 1935, contained exclusively drupes and berries. At this time Elaenias were found to be very abundant in the vicinity of Mosquito Bay. Many were heard singing on Great Thatch Island while passing close to its shores in a sailing vessel on January 4, 1934. On Jost van Dyke three were heard calling on January 1, 1934. The stomach of a male collected December 31, 1933, at Brandywine Bay, Tortola, contained one fruit seed. Two were noted on Beef Island December 28, 1933.

\section{Progne dominicensis (Gmelin) Caribbean Martin}

At Frederiksted, St. Croix, twenty were seen on July 23, 1933.

\section{Mimus polyglottos orpheus (Linnaeus) Jamaican Mockingbird}

On Culebra the Mockingbird is rather generally distributed, but it can scarcely be said to be very common. Males were collected December 27 and 28, 1934, and January 2, 1935, and a female January 3,1935 . The four stomachs contained 94.5 per cent of vegetable matter (drupes 30.7 per cent, berries 25 per cent, large flat seeds 22.5 per cent, and grass 16.3 per cent); and animal matter 5.5 per cent (Lepidopterous larvae).

On Cayo Norte Mockingbirds were locally common in the xerophytic scrub. A male was collected on December 30, 1934, and its stomach was found to contain exclusively berries. A juvenile bird collected at Mosquito Bay, St. Thomas, on June 17, 1935, was found to have eaten nothing but small wild fruits. 


\section{Margarops fuscatus fuscatus (Vieillot) Pearly-eyed Thrasher}

This species is of local distribution in the Virgin Islands, very common in some places, and rare or absent in others, without any apparent reason. At the time of my visit to Culebra it was rare there, only one being noted (on January 3, 1935). On Louis Peña on December 28, 1934, it was found to be one of the most abundant birds in the denser woods. A nest was discovered in a hole formed: in the crotch of a tree where the trunk divided into two parts, leaving a hole opening towards the top; the hollow inside was nearly two feet deep, and curved slightly away from the opening so that the end of the hollow was not directly beneath it. There a crude nest had been formed of sticks and stems of plants. As the nesthole was approached, two fledglings fluttered out. One made good its escape, the other was captured and preserved as a specimen. A parent thrasher remained close by while the nest was being examined. It was much excited and very solicitous for the welfare of its young, uttering frequent cat-like calls. The young had the iris dark brown; bill light straw color more or less tinged with dusky, especially on the upper mandible; legs and feet bluish gray; soles light straw color; claws bluish gray of a somewhat darker shade than the legs. Its stomach contained 4 large-seeded drupes. An adult male was also collected on Louis Peña the same day. Its stomach contained fragments of a weevil, 25 per cent; and fragments of a fruit of the "cundeamor", Momordica charantia, 75 per cent.

On Culebrita this thrasher was found to be fairly common on January 1, 1935, but none were seen on Cayo Norte, and Don Eduardo Padró, who has lived on Cayo Norte most of his life, and knows the bird well on other nearby islands, states positively that it does not occur there. It was fairly common on Jost van Dyke January 1, 1934, and a female was collected. Its stomach contained 9 large flat seeds of Cassia.

On St. Thomas this species was found to be exceptionally abundant near the west end in June, 1935. The stomach of one collected there on June 17 contained small wild fruits and seeds; that of another 6 Surinam Cherries.

Vireo calidris calidris (Linnaeus) Jamaican Vireo

Observed on St. Thomas June 16 and August 14, 1931; July 21 and 22, 1933; and June 14 and 15, 1935. On the latter date a: 
pair was collected on Signal Hill. One stomach contained 2 caterpillars and a green cockroach; the other 3 small wild fruits.

\section{Coereba portoricensis sancti-thomae (Sundevall) Virgin Island Honey Creeper}

Common practically throughout the Virgin Islands (except St. Croix). On Culebra it was common from December 26, 1934, to January 3, 1935. Three were collected on December 27. One stomach contained 5 Persicaria-like seeds and 2 small pieces of white seashell; another had two black lepidopterous larvae. On Louis Peña eight were noted and one collected on December 28, 1934; its stomach contained fragments of a small beetle. Twelve were seen and two collected on Culebrita January 1, 1935. One stomach contained 8 small, black Persicaria-like seeds, and the other 2 small lepidopterous larvae. On Cayo Norte December 30, 1934, the species was common, and two were collected. The stomach of one was empty; the other contained a small seed and some insect fragments.

Two Honey Creepers were collected on December 24 and 25, 1933, on St. Thomas. One had eaten 2 small caterpillars, the other stomach had some insect fragments and a little sand. The species was common on Jost van Dyke January 1, 1934. The stomach of a specimen collected there contained 18 Persicaria-like seeds. A Honey Creeper collected at Brandywine Creek, Tortola on December 31, 1933, had eaten a pink caterpillar. On Beef Island December 28, 1933, a newly constructed nest was found, made of grasses with the addition of some wild cotton.

Honey Creepers apparently feed extensively on the nectar of flowers, which does not show up in the stomach examinations. The presence of Persicaria-like seeds in rather large proportions in a number of the stomachs is rather surprising. Possibly the seeds are swallowed accidentally while searching for other food.

\section{Compsothlypis americana pusilla (Wilson) \\ Northern Parula Warbler}

One was observed on Jost van Dyke on January 1, 1934.

\section{Dendroica petechia cruciana Sundevall Puerto Rican Golden Warbler}

Common and generally distributed in the Virgin Islands. On Culebra it was common from December 26, 1934 to January 3, 1935. The stomachs of four specimens collected there contained comminuted 
insects, of which Coleoptera formed a large portion. Three were seen on Louis Peña December 28, 1934, and a male collected; its stomach was filled with comminuted insects. On Culebrita three were noted on January 1, 1935. The stomach of a female collected there contained insects too much macerated to permit of identification. Three were also seen on Cayo Norte December 30, 1934. The stomach contents of a male collected there resembled those of birds of the same species collected on other islands. On June 18, 1935, these warblers were found to be common near the diminutive lagoons on Little Saba, and a female was collected. On Jost van Dyke two were heard singing at Great Harbour on January 1, 1934, and the song of this species was also heard on Beef Island December 28, 1933.

\section{Dendroica castanea (Wilson) \\ Bay-breasted Warbler}

Mr. Beatty has forwarded an adult male collected at Fairplain Pastureland, St. Croix on May 5, 1935. This constitutes the first West Indian record of the species. It is now No. 1505 in my collection.

\section{Dendroica discolor discolor (Vieillot) Prairie Warbler}

Two were observed and a male collected on the north side of Culebra December 27, 1934. Its stomach contained comminuted insects, mainly small Coleoptera.

\section{Seiurus motacilla (Vieillot) \\ Louisiana Water-thrush}

A specimen is at hand obtained by Mr. Beatty at Crique Stream, St. Croix, on November 18, 1933.

\section{Seirus noveboracensis noveboracensis (Gmelin) Water-thrush}

Fairly common from December 26, 1934, to January 3, 1935, on Culebra, where one was collected on December 29. Five were seen on Jost van Dyke January 1, 1934. The stomach of a female collected on Tortola December 30, 1933 contained finely comminuted insects and a little sand. Four were noted and a female collected on Beef Island December 28, 1933. Its stomach contained insects and a few Persicaria seeds, a little sand, and a small piece of coral. Mr. Beatty 
sent me a male taken at Williams Pond, St. Croix, on April 1, 1934, and a male (?) secured at Prosperity Garden Water Hole, St. Croix: April 2, 1934.

\section{Tiaris bicolor omissa Jardine \\ Carib Grassquit}

Common and generally distributed in the Virgin Islands. On Culebra it was common, and three males and two females were collected between December 26, 1934, and January 3, 1935. A nest with three eggs, placed in a tree five feet above the ground, was also collected on the latter date. On Louis Peña twenty were noted on December 28, 1934, and a male bird, together with a nest with three eggs, were collected there. The nest was found in a spiny acacia tree four and a half feet from the ground.

On Culebrita the species was common January 1, 1935, and a male was collected. On Cayo Norte these grassquits were common January 1, 1935, and a pair was collected. They were also common and a female was collected on Jost van Dyke January 1, 1934. A male was collected at Brandywine Creek, Tortola, December 31, 1933. Ten were noted on Beef Island December 28, 1933. The stomach of all specimens collected contained small seeds. 


\section{LIST OF BIRDS KNOWN TO OCCUR IN THE VIRGIN ISLANDS (INCLUDING VIEQUES, CULEBRA AND ADJACENT ISLETS)}

1. Podilymbus podiceps antillarum Bangs. Antillean Grebe. Vieques (?), Culebra (?), Virgin Gorda, St. Croix.

2. Puffinus lherminieri lherminieri Lesson. Audubon's Shearwater. St. Thomas, Little Saba.

3. Phaëthon lepturus catesbyi Brandt. Yellow-billed Tropic Bird. I souis Peña, Congo Cay (between St. Thomas and St. Jan).

4. Pelecanus occidentalis occidentalis Linnaeus. Brown Pelican. Vieques, Culebra, Louis Peña, Culebrita, Cayo Norte, St. Thomas, St. Jan, Great Thatch Island, Jost van Dyke, Tortola, Beef Island, Salt Island, Virgin Gorda, St. Croix.

5. Sula leucogaster leucogaster (Boddaert). Brown Booby. Vieques, Culebra, Louis Peña, Culebrita (?), St. Thomas, Little Saba, St. Jan, Great Thatch Island, Jost van Dyke, Tortola, St. Croix.

6. Fregata magnificens rothschildi Mathews. Man-o-war Bird. Vieques, Culebra, Louis Peña, Culebrita, St. Thomas, St. Jan, Jost van Dyke, Tortola, Beef Island, St. Croix.

7. Ardea herodias herodias Linnaeus. Great Blue Heron. Culebra, Culebrita, St. Thomas, Tortola, St. Croix.

8. Casmerodius albus egretta (Gmelin). American Egret. Vieques, St. Thomas, St. Croix.

9. Leucophoyx thula thula (Molina). Snowy Egret. Vieques, St. Thomas, St. Croix.

10. Hydranassa tricolor ruficollis (Gosse). Louisiana Heron. St. Thomas.

11. Florida caerulea caerulescens (Latham). Southern Little Blue Heron. Vieques, Culebra, Louis Peña, Cayo Norte, St. Thomas, St. Jan, Jost van Dyke, Tortola, St. Croix.

12. Butorides virescens maculatus (Boddaert). West Indian Green Heron. Vieques, Culebra, Culebrita, Cayo Norte, St. Thomas, St. Jan. Jost van Dyke, Tortola, Virgin Gorda, Anegada, St. Croix.

13. Nycticorax nycticorax hoactli (Gmelin). Black-crowned Night Heron. St. Croix.

14. Nyctanassa violacea violacea (Linnaeus). Yellow-crowned Night Heron. Vieques, Culebra, St. Thomas, Tortola, Virgin Gorda, St. Croix. 
15. Phoenicopterus ruber Linnaeus. Flamingo. Formerly Vie-ques, Culebra, St. Thomas, and St. Croix (?), St. Jan(?), Anegada(?).-

16. Dendrocygna arborea (Linnaeus). West Indian Tree Duck. Virgin Gorda, St. Croix.

17. Dendrocygna autumnalis discolor Sclater and Salvin. Blackbellied Tree Duck. St. Croix.

18. Anas platyrhynchos platyrhynchos Linnaeus. Mallard. St. Croix.

19. Anas discors Linnaeus. Blue-winged Teal. St. Croix.

20. Mareca americana (Gmelin). Baldpate. St. Thomas, St. Croix.

21. Dafila acuta tzitzihoa (Vieillot). Pintail. St. Croix.

22. Dafila bahamensis bahamensis (Linnaeus). Bahama Duck. Culebra, Culebrita, St. Thomas, Jost van Dyke, Beef Island, Virgin Gorda, St. Croix.

23. Spatula clypeata (Linnaeus). Shoveller. St. Thomas.

24. Nyroca affinis (Eyton). Lesser Scaup Duck. Vieques, Culebra, Virgin Gorda, St. Croix.

25. Erismatura jamaicensis jamaicensis (Gmelin). West Indian Ruddy Duck. St. Croix.

26. Buteo jamaicensis jamaicensis (Gmelin). West Indian Redtailed Hawk. Vieques, Culebra, Cayo Norte, St. Thomas, St. Jan, Jost van Dyke, Tortola, St. Croix.

27. Pandion haliaëtus carolinensis (Gmelin). Osprey. Vieques, Culebra, Tortola, Salt Island, St. Croix.

28. Falco peregrinus anatum Bonaparte. Duck Hawk. Salt Island, Virgin Gorda, St. Croix.

29. Falco columbarius columbarius Linnaeus. Pigeon Hawk. St. Thomas, Virgin Gorda.

30. Falco sparverius loquaculus (Riley). Puerto Rican Sparrow Hawk. Vieques, Culebra, Louis Peña, Culebrita, Cayo Norte, St. Thomas, St. Jan, Jost van Dyke, Tortola, Virgin Gorda, St. Croix.

31. Colinus virginianus virginianus (Linnaeus). Quail. St. Croix (introduced).

32. Colinus cristatus sonnini (Temminck). Crested Quail. St. Thomas (introduced; now extinet).

33. Rallus longirostris subsp. Clapper Rail. Vieques, Culebra, St. Thomas, Tortola, St. Croix.

34. Porzana carolina (Linnaeus). Sora Rail. Tortola, St. Croix.

35. Nesotrochis debooyi Wetmore. De Booy's Rail. St. Thomas and St. Croix (fossil). 
36. Gallinula chloropus portoricensis Danforth. Antillean Gallinule. Vieques, Culebra, Cayo Norte, St. Thomas, Jost van Dyke, Tortola, Beef Island, Virgin Gorda, St. Croix.

37. Fulica americana americana Gmelin. American Coot. St. Croix.

38. Fulica caribaea Ridgway. Caribbean Coot. Culebra, St. Jan, Jost van Dyke, Beef Island, St. Croix.

39. Haematopus palliatus prattii Maynard. Bahaman Oystercatcher. Culebra, Louis Peña, Culebrita, Cayo Norte, St. Thomas, Tortola.

40. Charadrius vociferus vociferus Linnaeus. Killdeer. Culebra, Cayo Norte, St. Thomas, Salt Island, Virgin Gorda, Anegada, St. Croix.

41. Charadrius vociferus ternominatus Bangs and Kennard. Antillean Killdeer. Vieques, St. Thomas (?).

42. Charadrius hiaticula semipalmatus Bonaparte. Semipalmated Plover. Vieques, Anegada, St. Croix.

43. Charadrius alexandrinus tenuirostris (Lawrence). Cuban Snowy Plover. St. Croix.

44. Pagolla wilsonia rufinucha (Ridgway). Rufous-naped Plover. Vieques, Culebra, St. Thomas, Little Saba, Virgin Gorda, Anegada, St. Croix.

45. Pluvialis dominica dominica (Müller). Golden Plover. St. Croix.

46. Squatarola squatarola cynosurae Thayer and Bangs. Blackbellied Plover. St. Croix.

47. Arenaria interpres morinella (Linnaeus). Ruddy Turnstone. Cullebra, Culebrita, Tortola, St. Croix.

48. Capella delicata (Ord). Wilson's Snipe. Tortola, St, Croix.

49. Numenius phaeopus hudsonicus Latham. Hudsonian Curlew. Anegada, St. Croix.

50. Actitis macularia (Linnaeus). Spotted Sandpiper. Vieques, Culebra, Louis Peña, St. Thomas, St. Jan. Jost van Dyke, Tortola. Virgin Gorda, St. Croix.

51. Tringa solitaria solitaria Wilson. Solitary Sandpiper. St. Croix.

52. Tringa flavipes (Gmelin). Lesser Yellowlegs. Vieques, St. Thomas, Tortola, Anegada, St. Croix.

53. Tringa melanoleuca (Gmelin). Greater Yellowlegs. Beef Island, St. Croix. 
54. Catoptrophorus semipalmatus semipalmatus (Gmelin). Willet. Anegada, St. Croix.

55. Catoptrophorus semipalmatus inornatus (Brewster). Western Willet. St. Croix.

56. Limnodromus griseus griseus (Gmelin). Dowitcher. St. Croix.

57. Limnodromus griseus scolapaceus (Say). Long-billed Dowitcher. Anegada.

58. Calidris canutus rufus (Wilson). Knot. St. Croix.

59. Crocethia alba (Pallas). Sanderling. St. Croix.

60. Ereunetes pusillus (Linnaeus). Semipalmated Sandpiper. St. Thomas, Anegada, St. Croix.

61. Ereunetes mauri Cabanis. Western Sandpiper. Beef Island.

62. Erolia mimutilla (Vieillot). Least Sandpiper. St. Croix.

63. Erolia melanotos (Vieillot). Pectoral Sandpiper. St. Croix.

64. Erolia fuscicollis (Vieillot). White-rumped Sandpiper. Culebrita.

65. Micropalama himantopus (Bonaparte). Stilt Sandpiper. Anegada, St. Croix.

66. Limosa fedoa (Linnaeus). Marbled Godwit. St. Croix.

67. Himantopus himantopus mexicanus (Müller). Black-necked Stilt. Vieques, St. Thomas, Little Saba, Tortola, St. Croix.

68. Larus atricilla Linnaeus. Laughing Gull. Vieques, Culebra, Culebrita, St. Thomas, Little Saba, St. Croix.

69. Sterna daugallii dougallii Montagu. Roseate Tern. St. Thomas, Little Saba, St. Croix.

70. Sterna albifrons antillarum (Lesson). Least Tern. St. Thomas, St. Croix.

71. Sterna anaethetus melanoptera Swainson. Bridled Tern. St. Thomas, Little Saba.

72. Sterna fuscata fuscata Linnaeus. Sooty Tern. St. Thomas, Little Saba, Tortola (?), St. Croix.

73. Thalasseus maximus maximus (Boddaert). Royal Tern. Vieques, Culebra, Culebrita, St. Thomas, St. Jan, Jost van Dyke, Tortola, Anegada, St. Croix.

74. Anoüs stolidus stolidus (Linnaeus). Noddy Tern. St. Thomas, Little Saba, St. Croix (?).

[Rhynchops nigra nigra Linnaeus. Black Skimmer. St. Croix (?).]

75. Columba leucocephala Linnaeus. White-crowned Pigeon. Vieques, Culebra, Virgin Gorda, St. Croix. 
76. Columba squamosa Bonnaterre. Scaled Pigeon. Vieques, Culebra, Louis Peña, Culebrita, Cayo Norte, St. Thomas, St. Jan, Tortola, St. Croix.

[Crossopthalmus gymnopthalmus (Temminck). Bare-eyed Pigeon. St. Thomas (?).]

77. Zenaida aurita zenaida (Bonaparte). Zenaida Dove. Vieques, Culebra, Louis Peña, Culebrita, St. Thomas, Little Saba, St. Jan, Tortola, Salt Island, Virgin Gorda, St. Croix.

78. Zenaida aurita aurita (Temminck). Martinique Dove. Virgin Gorda, St. Croix.

79. Columbigallina passerina portoricensis (Lowe). Puerto Rican Ground Dove. Vieques, Culebra, Louis Peña, Culebrita, Cayo Norte, St. Thomas, Little Saba, St. Jan, Jost van Dyke, Tortola, Beef Island, Salt Island, Virgin Gorda, Anegada.

79 a. Columbigallina passerina nigrirostris Danforth. St. Kitts Ground Dove. St. Croix.

80. Oreopeleia montana (Linnaeus). Ruddy Quail Dove. Vieques, St. Thomas, St. Croix (formerly).

81. Oreopeleia mystacea mystacea (Temminck). Bridled Quail Dove. Culebra (formerly), St. Croix.

82. Amazona vittata gracilipes Ridgway. Culebra Parrot. Culebra (extinct).

83. Eupsittula pertinax pertinax (Linnaeus). Curaçao Paroquet. St. Thomas.

84. Coccyzus americanus americanus (Linnaeus). Yellow-billed Cuckoo. St. Croix.

85. Coccyzus minor teres Peters. Mangrove Cuckoo. Vieques, Culebra, Louis Peña, Culebrita, Cayo Norte, St. Thomas, St. Jan, Jost van Dyke, Tortola, Virgin Gorda, St. Croix.

86. Saurothera vieilloti (Bonaparte). Puerto Rican Lizard Cuckoo. Vieques, St. Thomas (formerly).

87. Crotophaga ani Linnaeus. Ani. Vieques, Culebra, Louis Peña, Culebrita, Cayo Norte, St. Thomas, St. Jan, Jost van Dyke, Tortola, Beef Island, Salt Island, Virgin Gorda, Anegada, St. Croix.

88. Gymnasio mudipes newtoni (Lawrence). Newton's Owl. Vieques (?), St. Thomas, St. Jan, St. Croix. Extinct.

89. Antrostomus carolinensis ( $\mathrm{Gmelin}$ ). Chuck-will's-widow. Vieques, St. Croix.

90. Nephoecetes niger niger (Gmelin). West Indian Black Swift. St. Croix.

91. Orthorhynchos exilis exilis (Gmelin). Gilt-crested Hummingbird. Vieques, Culebra, Culebrita, Cayo Norte, St. Thomas, St. Jan, 
Jost van Dyke, Tortola, Salt Island, Virgin Gorda, Anegada, St. Croix.

92. Sericotes holosericeus holosericeus (Linnaeus). Blue-breasted Hummingbird. Vieques, Culebra, Culebrita, Cayo Norte, St. Thomas, Little Saba, St. Jan, Tortola, Beef Island, Salt Island, Virgin Gorda, Anegada, St. Croix.

93. Anthracothorax aurulentus (Audebert and Vieillot). Puerto Rican Mango Hummingbird. Vieques, Culebra, Culebrita, St. Thomas. St. Jan, Anegada.

94. Megaceryle alcyon alcyon (Linnaeus). Belted Kingfisher. Vieques, Culebra, Louis Peña, Culebrita, Cayo Norte, St. Thomas, St. Jan, Jost van Dyke, Tortola, St. Croix.

95. Melanerpes portoricensis (Daudin). Puerto Rican Woodpecker. Vieques.

96. Sphyrapicus varius varius (Linnaeus). Yellow-bellied Sapsucker. St. Croix.

97. Tyrannus dominicensis dominicensis (Gmelin). Gray Kingbird. Vieques, Culebra, Louis Peña, Culebrita, Cayo Norte, St. Thomas, St. Jan, Jost van Dyke, Great Thatch Island, Tortola, Beef Island, Salt Island, Virgin Gorda, Anegada, St. Croix.

98. Tolmarchus taylori (Sclater). Puerto Rican Petchary. Vieques.

99. Myiarchus antillarum (Bryant). Puerto Rican Flycatcher. Vieques.

100. Elaenia martinica riisii Sclater. Riise's Elaenia. Vieques, Culebra, Louis Peña, Culebrita, Cayo Norte, St. Thomas, St. Jan, Jost van Dyke, Great Thatch Island, Tortola, Beef Island, Virgin Gorda, Anegada, St. Croix.

101. Hirundo erythrogaster Boddaert. Barn Swallow. St. Thomas, St. Croix.

102. Progne dominicensis (Gmelin). Caribbean Martin. Vieques, St. Croix.

103. Corvus leucognaphalus Daudin. Puerto Rican Crow. St. Croix (extinct).

104. Mimus polyglottos orpheus (Linnaeus). Jamaican Mockingbird, Vieques, Culebra, Culebrita, Cayo Norte, St. Thomas, St. Jan, Tortola, Salt Island, Virgin Gorda, St. Croix.

105. Margarops fuscatus fuscatus (V ieillot). Pearly-eyed Thrasher. Vieques, Culebra, Louis Peña, Culebrita, St. Thomas, St. Jan, Jost van Dyke, Tortola, Virgin Gorda, St. Croix.

106. Vireo calidris calidris (Linnaeus). Jamaican Vireo. Vieques, Louis Peña, Culebrita, St. Thomas, St. Croix. 
107. Coereba portoricensis sancti-thomae (Sundevall). Virgin Islands Honey Creeper. Vieques, Culebra, Louis Peña, Culebrita, Cayo Norte, St. Thomas, St. Jan, Jost van Dyke, Tortola, Beef Island, Virgin Gorda, Anegada.

108. Coereba newtoni (Baird). St. Croix Honey Creeper. St. Croix.

109. Mniotilta varia (Linnaeus). Black and White Warbler. Vieques, Culebra, St. Thomas, St. Croix.

110. Compsothlypis americana pusilla (Wilson). Northern Parula Warbler. Vieques, Culebra, Louis Peña, St. Thomas, Jost van Dyke, Tortola, Virgin Gorda, St. Croix.

111. Dendroica tigrina (Gmelin). Cape May Warbler. Vieques, St. Thomas, St. Croix.

112. Dendroica petechia cruciana Sundevall. Puerto Rican Golden Warbler. Vieques, Culebra, Louis Peña, Culebrita, Cayo Norte, St. Thomas, Little Saba, St. Jan, Jost van Dyke, Tortola, Beef Island, Virgin Gorda, Anegada, St. Croix.

113. Dendroica caerulescens caerulescens (Gmelin). Blackthroated Blue Warbler. Vieques.

114. Dendroica coronata (Linnaeus). Myrtle Warbler. Vieques, Culebra.

115. Dendroica virens virens (Gmelin). Black-throated Green Warbler. St. Croix.

[Dendroica dominica dominica (Linnaeus). Yellow-throated Warbler. St. Thomas (?).]

116. Dendroica adelaidae Baird. Adelaide's Warbler. Vieques.

117. Dendroica castanea (Wilson). Bay-breasted Warbler. St. Croix.

118. Dendroica discolor discolor (Vieillot). Prairie Warbler. Vieques, Culebra, St. Thomas, St. Jan, Tortola, Virgin Gorda.

119. Dendroica palmarum palmarum (Gmelin). Palm Warbler. St. Croix.

120. Seiurus aurocapillus (Linnaeus). Oven-bird. Vieques, Culebra, St. Thomas, Tortola, St. Croix.

121. Seiurus noveboracensis noveboracensis (Gmelin). Waterthrush. Culebra, Louis Peña, St. Thomas, St. Jan, Jost van Dyke, Tortola, Beef Island, Virgin Gorda, St. Croix.

122. Seiurus noveboracensis notabilis Ridgway. Grinnell's Waterthrush. Culebra, St. Croix.

123. Seiurus motacilla (Vieillot). Louisiana Water-thrush. Vieques, St. Croix. 
124. Wilsonia canadensis (Linnaeus). C a n a d a Warbler. St. Croix.

125. Setophaga ruticilla (Linnaeus). Redstart. Vieques, Culebra, Louis Peña, St. Thomas, St. Jan, Tortola, Virgin Gorda, St. Croix.

126. Dolichonyx oryzivorus (Linnaeus)'. Bobolink. Vieques.

127. Icterus icterus ridgwayi (Hartert). Troupial. St. Thomas.

128. Holoquiscalus niger brachypterus (Cassin). Puerto Rican Grackle. Vieques, Culebra (?). Introduced in St. Croix.

129. Molothrus bonariensis minimus Dalmas. Dwarf Cowbird. Vieques (accidental).

130. Piranga erythromelas Vieillot. Scarlet Tanager. Tortola (?), St. Croix.

131. Tiaris bicolor omissa Jardine. Carib Grassquit. Vieques, Culebra, Louis Peña, Culebrita, Cayo Norte, St. Thomas, St. Jan, Jost van Dyke, Tortola, Beef Island, Salt Island, Virgin Gorda, Anegada, St. Croix.

132. Tiaris olivacea bryanti (Ridgway). Bryant's Grassquit. Vieques, Culebra. 